\title{
Hepatitis C and Hepatitis B Virus Infection in Different Hemodialysis Units in Belo Horizonte, Minas Gerais, Brazil
}

\author{
Solange U Busek/*, Élio H Babá*, Hélcio A Tavares Filho**, Lermíno Pimenta***, \\ Abraão Salomão****, Rodrigo Corrêa-O liveira, Guilherme C Oliveira/*****/+
}

\begin{abstract}
Centro de Pesquisas René Rachou-Fiocruz, Av. Augusto de Lima 1715, 30190-002 Belo Horizonte, MG, Brasil *DECBI/ NUPEB, Universidade Federal de Ouro Preto, Ouro Preto, MG, Brasil **Hospital Biocor, Belo Horizonte, MG, Brasil ***Santa Casa de Misericórdia, Belo Horizonte, MG, Brasil ****Instituto Mineiro de Nefrologia, Belo Horizonte, MG, Brasil ******Programa de Pós-Graduação e Pesquisa, Santa Casa de Misericórdia, Belo Horizonte, MG, Brasil
\end{abstract}

The prevalence, virological and epidemilogical aspects of the hepatitis $C$ virus $(H C V)$ and the hepatitis $B$ virus $(H B V)$ infections vary among hemodialysis patients in different countries. Aiming at analyzing these aspects of $H C V$ and HBV infections in hemodialysis patients in Belo Horizonte, MG, Brazil, we studied three hemodialysis units including 434 patients. Serology was used to detect anti-HCV and HBsAg. Reverse trancriptase nested polymerase chain reaction (RT-nested-PCR) of the 5'-noncoding region was used to detect circulating HCV RNA and restriction fragment length polymorphism analysis for genotyping. Seroprevalence varied from $26.5 \%$ to $11.1 \%$ for hepatitis C and from 5.9\% to $0 \%$ for hepatitis B. Risk factors observed for HBV and/or HCV infections were the number of patients per dialysis unit, duration of treatment, number of clinics attended, number of blood units transfused, and lower level scholarity. Alanine aminotransferase levels were altered with a higher frequency in $H B V$ or $H C V$ seropositive patients. Half of ten patients, negative for anti-HCV, had detectable viremia by RT-nested-PCR, indicating that this technique should be used to confirm infections in this group of patients. The HCV genotype 1 was the most frequently observed, followed by the genotype 2, but no correlation was detected between genotype and clinical or epidemiological data.

Key words: alanine aminotransferase - hepatitis C virus genotype - hemodialysis - hepatitis B - hepatitis C - prevalence Belo Horizonte - Brazil

The hepatitis C and B viruses (HCV and HBV) are highly prevalent in hemodialysis patients (Tokars et al. 1995, Wreghitt 1999). The high levels of prevalence have been related to the duration of the dialysis treatment and the number of blood units transfused (Wreghitt 1999). Nosocomial transmission of HCV and HBV also appears to be an important contributing factor to the spread of these viruses (Castro-Figueiredo et al. 1986, Teles et al. 1998, Wreghitt 1999, Carneiro et al. 2001). The prevalence of the HBV has drastically reduced with control practices, but outbreaks are still frequent and routine screening necessary (Wreghitt 1999, Lewis-Ximenez et al. 2001).

The HCV is a positive-stranded RNA molecule of approximately 10,000 nucleotides (Choo et al. 1989). Based on genome sequence, at least six main genotypes, with varying geographical distribution, have been observed for HCV (Takada et al. 1993, McOmish et al. 1994, Bukh et al. 1995). These genotypes appear to be clinically relevant in relation to virulence and chemotherapy response (Hopf et al. 1996).

In Brazil, high anti-HCV prevalences within hemodialysis units have been observed (Oliveira GC et al. 1999,

This study was supported by Capes, Ufop and Papes-Fiocruz. ${ }^{+}$Corresponding author. Fax: +55-31-3295.3115. E-mail: oliveira@cpqrr.fiocruz.br

Received 26 December 2001

Accepted 3 May 2002
Carneiro et al. 2001). The distribution of HCV genotype is similar to that observed in Europe, with the predominance of the genotype 1 followed by the genotype 3 (Oliveira GC et al. 1999, Oliveira MLA et al. 1999). HBV prevalence was found to be highly variable, from 2 to $78 \%$ in hemodialysis clinics (Teles et al. 1998).

The aim of the present study was to investigate the epidemiological and clinical features of HCV and HBV infections and the distribution of HCV genotypes in hemodialysis patients, in three different hemodialysis units in Belo Horizonte, MG, Brazil.

\section{MATERIALS AND METHODS}

Patients - Clinical and epidemiological data were obtained from March to December 2000 in three hemodialysis units in Belo Horizonte, MG, Brazil, from a total of 434 hemodialysis patients. Age varied from 18 to 94 with an average of 50 years of age. Male patients comprised $56.3 \%$ of the studied population. Patients were under treatment at three different hemodialysis centers, each with 54, 169 and 211 patients. Formal consent to participate was obtained from all patients. The ethical and methodological aspects of this study received Research Ethics Committee approval.

Serological assays - Serum samples were tested for anti-HCV by using third-generation enzyme immunoassay (EIA.3.0, Abbott Laboratories, Chicago, IL) (units 1 and 2) or ImmunoComb II (Orgenics, Israel) (unit 3). Samples were tested for HBsAg by ELISA (Auszyme Monoclonal, Abbott Park, IL, USA). Serum alanine aminotransferase (ALT) activity was monthly determined 
since seroconversion to HCV or HBV by using the ALTRandox (Randox Laboratories, San Diego, CA). ALT levels were considered to be elevated when 1.5 times above the maximum normal value, 8-40 UI/l. ALT levels were considered intermittent, when observed to be elevated in a single determination, or persistent when elevated for at least three consecutive determinations.

Detection and genotyping of HCV RNA - HCV RNA detection was performed by reverse transcriptase nested polymerase chain reaction (RT-nested-PCR) of the 5' noncoding region, and genotyping by restriction fragment length polymorphism (RFLP) of the amplified product, as previously described (Oliveira GC et al. 1999), for all antiHCV positive patients. For control reactions, in addition to amplifications with no template, we tested 10 random samples of anti-HCV-hemodialysis negative patients.

Statistical analysis - Fisher's exact and the Chi-square tests were applied with Yate's correction for the analysis of the data; $\alpha<0.05$.

\section{RESULTS}

The average prevalence of seropositivity to $\mathrm{HCV}$ infection (anti- $\mathrm{HCV}^{+}$), among 434 hemodialysis patients, was $20.3 \%, 4.6$ times higher than that observed for HBV $(4.4 \%)$. Co-infection was observed in only two patients $(0.4 \%)$. HCV infection prevalence was significantly different among units $(\mathrm{P}<0.05)$. Unit 2 showed the highest prevalence $(26.5 \%)$ followed by unit $3(15.5 \%)$ and unit 1 $(11.1 \%)$. The prevalence of $\mathrm{HBV}$ infection $\left(\mathrm{HBsAg}^{+}\right)$was similar between units 2 and 3 (4.3 and 5.9\% respectively), and unit 1 did not have any case of $\mathrm{HBsAg}^{+}$(Table I).

The prevalence of HCV RNA among $88 \mathrm{HCV}$ seropositive patients was $94.3 \%$. Two out of 10 patients with indeterminate serology had detectable HCV RNA. In addition, of 10 patients with negative serology 5 had detectable HCV RNA. Hepatitis C virus genotype was determined for $83 \mathrm{HCV}$ RNA positive patients. Genotype 1 was the most common (66.3\%), followed by genotype $2(24.1 \%)$ and genotype $3(7.2 \%)$. Genotype 4 was detected in only one patient (1.2\%) and in another patient the amplified fragment was not typeable by RFLP. Despite the predominance of the genotype 2 in unit 1 , there was not a statistically significant difference in the genotype distribution among the three hemodialysis units (Table II).

A higher prevalence of $\mathrm{HCV}$ was observed in patients with the lowest educational levels $(\mathrm{P}<0.05)$. No correlation among HCV prevalence and sex, race, place of residence and marital status was observed (data not shown). The use of multiple hemodialysis units and the duration of treatment were important factors for the acquisition of both HCV and HBV infections in dialysis patients. However, an elevated number of blood transfusions (seven or more) were correlated only to the HCV positivity (Table III).

TABLE I

Serological viral markers of hepatitis B and hepatitis C infections in three different hemodialysis units. Number of patients $(\%)$

\begin{tabular}{|c|c|c|c|c|}
\hline & \multicolumn{4}{|c|}{ Serological profile $^{a}$} \\
\hline & $\mathrm{HCV}^{-} / \mathrm{HBV}^{-}$ & $\mathrm{HCV}^{+}, b$ & $\mathrm{HBV}^{+}$ & $\mathrm{HCV}^{+} / \mathrm{HBV}^{+}$ \\
\hline Unit 1 & $48(88.9)$ & $6(11.1)$ & 0 & 0 \\
\hline Unit 2 & $145(68.7)$ & $56(26.5)$ & $9(4.3)$ & $1(0.5)$ \\
\hline Unit 3 & $132(78.1)$ & $26(15.5)$ & $10(5.9)$ & $1(0.5)$ \\
\hline Total & 325 (74.9) & $88(20.3)$ & $19(4.4)$ & $2(0.4)$ \\
\hline
\end{tabular}

$a: \mathrm{HCV}=$ anti-HCV; HBV $=\mathrm{HBsAg} ; b: \mathrm{P}<0.05$

TABLE II

Distribution of hepatitis $\mathrm{C}$ virus (HCV) genotypes in three different hemodialysis units. Number of patients $(\%)$

\begin{tabular}{lccccc}
\hline & \multicolumn{5}{c}{ HCV genotypes } \\
\cline { 2 - 6 } & 1 & 2 & 3 & 4 & $\mathrm{~N} \mathrm{~T}$ \\
\hline Unit 1 & $1(16.6)$ & $3(50.0)$ & $1(16.6)$ & 0 & $1(16.6)$ \\
Unit 2 & $35(64.8)$ & $14(25.9)$ & $5(9.3)$ & 0 & 0 \\
Unit 3 & $19(82.6)$ & $3(13.1)$ & 0 & $1(4.3)$ & 0 \\
\hline Total & $55(66.3)$ & $20(24.1)$ & $6(7.2)$ & $1(1.2)$ & $1(1.2)$ \\
\hline
\end{tabular}

NT: not typeable by restriction fragment length polymorphism

TABLE III

Evaluation of risk factors among hepatitis B and hepatitis $\mathrm{C}$ infected patients. Number of patients (\%)

\begin{tabular}{|c|c|c|c|c|c|c|c|}
\hline Variable & NI & $\mathrm{HCV}^{+}$ & OR & $\mathrm{p}$ value & $\mathrm{HBV}$ & OR & $\mathrm{p}$ value \\
\hline \multicolumn{8}{|c|}{ Number of blood transfusions } \\
\hline 0 & $188(58.9)$ & $41(46.6)$ & 1.00 & - & $10(47.6)$ & - & 0.29 \\
\hline 1 to 6 & $120(37.6)$ & $39(44.3)$ & 1.49 & 0.14 & $9(42.9)$ & - & - \\
\hline 7 to 32 & $11(3.5)$ & $8(9.1)^{b}$ & 3.33 & 0.02 & $2(9.5)$ & - & - \\
\hline \multicolumn{8}{|c|}{ Use of more than one unit } \\
\hline No & $309(96.8)$ & $68(77.3)$ & 1.00 & - & $18(85.7)$ & 1.00 & - \\
\hline Yes & $10(3.3)$ & $20(22.7)^{b}$ & 9.09 & 0.00 & $3(14.3)^{b}$ & 5.15 & 0.04 \\
\hline \multicolumn{8}{|c|}{ Duration of hemodialysis } \\
\hline 1 year & $182(57.0)$ & $6(6.8)$ & 1.00 & - & $2(9.5)$ & 1.00 & - \\
\hline 2 to 8 years & $131(41.1)$ & $64(72.7)^{b}$ & 14.8 & 0.00 & $11(52.4)^{b}$ & 7.64 & 0.00 \\
\hline 9 to 19 years & $6(1.9)$ & $18(20.5)^{b}$ & 91.0 & 0.00 & $8(38.1)^{b}$ & 121.3 & 0.00 \\
\hline
\end{tabular}

NI: non infected patients; HCV: anti-HCV; HBV: HBsAg; $b$ : $\mathrm{p}<0.05$ 
A significantly higher number of patients with intermittently or persistently elevated ALT levels were observed for $\mathrm{HBsAg}^{+}$or anti-HCV viremic and seropositive patients, in comparison with seronegative (HBV and $\mathrm{HCV}$ ) and/or RT-PCR negative patients (Table IV). No correlation was found between the different genotypes and demographic characteristics, risk factors, ALT, serology, and viremia.

\section{DISCUSSION}

Hemodialysis patients are an important risk group for $\mathrm{HCV}$ infection. We observed a lower prevalence of anti$\mathrm{HCV}$ positive (20.3\%) patients when compared with other dialysis centers in Brazil (50\%) (Oliveira MLA et al. 1999, Carneiro et al. 2001), United States (average $=10.4 \%)$ (Tokars et al. 1998), Portugal (48\%) (Carrera et al. 1994) and Saudi Arabia (45.5\%) (al Nasser et al. 1992). Different prevalences of HCV infection were observed in the three hemodialysis units under study. It is known that different methods of control, cleaning and disinfection of the hemodialysis membranes, machines, instruments and environmental surfaces may interfere with determined prevalences (Wreghitt 1999). We observed that the prevalence was also positively correlated with an increased number of patients under treatment per unit. Another important observation of this study was that patients attending more than one treatment unit had nine times greater risk of being infected by HCV. Higher age and longer duration of hemodialysis treatment were also an important risk factor for HCV infection (Teles et al. 1998, Carneiro et al. 2001). As observed by others, the higher risk for $\mathrm{HCV}$, infection in patients with seven or more blood transfusions, is probably related to poor infection screening and control methods (Wreghitt 1999).

Serological tests are used worldwide for the screening of HCV infection. Some of the serological tests have shown up to $10 \%$ disagreement with PCR based tests (Garinis et al. 1999). In this paper, we describe confirmation of active infection by RT-nested-PCR in $94.3 \%$ of the patients studied. The unconfirmed cases may have been the result of a decrease in viral load observed in this group of patients (Furusyo et al. 2000). The occurrence of HCV RNA detectable in patients with negative anti-HCV can be a consequence of immunossupression with decreased production of antibodies, or the window period of a recent infection (Sharara et al. 1996, Lok \& Gunaratnam 1997). Another possibility is the absence, in the serology kits used, of an antigenic variant that is present in the geographic area studied (Dow et al. 1996). Other studies also detected HCV or HBV nucleic acids in anti-HCV negative or HBsAg-negative/IgM anti-HBc-positive hemodialysis patients, respectively (Carneiro et al. 2001, Lewis-Ximenez et al. 2001). The potential problem of a high prevalence of HCV RNA positive patients in an HCV seronegative group deserves to be studied in depth, due to the possible consequences to $\mathrm{HCV}$ transmission in hemodialysis centers. The genotype distribution of the $\mathrm{HCV}$ isolates in the units studied was not different from those previously reported from the same geographical area (Oliveira GC et al. 1999, Oliveira MLA et al. 1999), with a predominance of the genotype 1 . Nonetheless, somewhat elevated prevalence of the HCV genotype 2, which has been shown to be rare in Brazil, especially in unit 1, may suggest nosocomial transmission.

One of the important parameters measured in hepatitis virus infected patients are the levels of circulating ALT enzyme. We observed that a higher number of $\mathrm{HBsAg}^{+}$ or HCV positive (RNA and serology) patients had intermittently or persistently elevated ALT levels. However, a large number of these patients had normal ALT levels, indicating that this marker should be used in combination with other variables in the construction of a useful algorithm to determine patient clinical status for $\mathrm{HCV}$ and $\mathrm{HBV}$ infections.

\section{ACKNOWLEDGEMENTS}

To Drs Michele Hostalácio Duarte, Cláudia Ribeiro, André Duarte, Valério Rodrigues, Alcimar Gonçalves dos Santos, Acássia Lippi, Maria Paulina Pinto and the nurses of the three hemodialysis units for their help with collecting patient's information and samples.

\section{REFERENCES}

al Nasser MN, Al Mugeiren MA, Assuhaimi SA, Obineche E, Onwabalili J, Ramia S 1992. Seropositivity to hepatitis C virus in Saudi hemodialysis patients. Vox Sang 62: 94-97.

Bukh J, Miller RH, Purcell RH 1995. Genetic heterogeneity of hepatitis C virus: quasispecies and genotypes. Semin Liver Dis 15: 41-63.

Carneiro MA, Martins RM, Teles SA, Silva SA, Lopes CL, Cardoso DD, Vanderborght BO, Yoshida CF 2001. Hepatitis $\mathrm{C}$ prevalence and risk factors in hemodialysis patients in Central Brazil: a survey by polymerase chain reaction and serological methods. Mem Inst Oswaldo Cruz, 96: 765-769.

Carrera F, Silva JG, Oliveira C, Frazão JM, Pires C 1994. Persistence of antibodies to hepatitis $\mathrm{C}$ virus in a chronic hemodialysis population. Nephron 68: 38-40.

Castro-Figueiredo JF, Moyses-Neto M, Gomes UA, Spalini-Ferraz A, Nardin-Batista ME, Coimbra-Gaspar AM, TachibanaYoshida CF 1986. Hepatitis B virus infection in hemodialysis units: clinical features, epidemiological markers and general control measures. Braz J Med Biol Res 19: 735-742.

TABLE IV

Prevalence of anti-HCV and HBsAg according to alanine aminotransferase (ALT) levels. Number of patients (\%)

\begin{tabular}{|c|c|c|c|c|c|c|c|}
\hline \multirow[b]{2}{*}{ ALT levels } & \multirow[t]{2}{*}{$\mathrm{HCV}^{-} / \mathrm{HBV}^{-}$} & \multirow[t]{2}{*}{$\mathrm{HBV}^{+}$} & \multicolumn{5}{|c|}{$\mathrm{HCV}^{+}$} \\
\hline & & & $\mathrm{Ser}^{+} / \mathrm{PCR}^{+} c$ & $\mathrm{Ser}^{+} / \mathrm{PCR}^{-}$ & SerI/PCR ${ }^{+}$ & SerI/PCR ${ }^{-}$ & $\mathrm{Ser}^{-} / \mathrm{PCR}^{+}$ \\
\hline Normal & $269(84.3)$ & $9(42.9)$ & $44(53)$ & $4(80)$ & $1(50)$ & $8(100)$ & $4(80)$ \\
\hline Intermittent & $48(15.1)$ & $10(47.6)^{b}$ & $35(42.2)^{b}$ & $1(20)$ & $1(50)$ & 0 & $1(20)$ \\
\hline Persistent & $2(0.6)$ & $2(9.5)^{b}$ & $4(4.8)^{b}$ & 0 & 0 & 0 & 0 \\
\hline
\end{tabular}

HCV: anti-HCV; HBV: HBsAg; Ser $^{+}$: negative serology; $b$ : $\mathrm{p}<0.05 ; c$ : Ser ${ }^{+}$: positive serology; SerI: indeterminate serology 
Choo Q-L, Kuo G, Weiner AJ, Overby LR, Bradley DW, Houghton M 1989. Isolation of a cDNA clone derived from a blood-borne non-A, non-B viral hepatitis genome. Science 244: 359-362.

Dow BC, Munro H, Buchanan I, Follett EA, Davidson F, Yap PL, Simmonds P 1996. Third-generation recombinant immunoblot assay: comparison of reactivities according to hepatitis C virus genotype. Transfusion 36: 547-551.

Furusyo NJ, Hayashi I, Ariyama Y, Sawayama Y, Etoh Y, Shigematsu M, Kashiwagi S 2000. Maintenance hemodialysis decreases serum hepatitis $\mathrm{C}$ virus (HCV) RNA levels in hemodialysis patients with chronic HCV infection. Am J Trop Med Hyg 95: 490-496.

Garinis G, Spanakis N, Theodorou V, Gorgoulis V, Manolis E, Karameris A, Valis D 1999. Comparison of the enzimelinked immunosorbant assay III, recombinant immunoblot third generation assay, and polymerase chain reaction method in the detection of hepatitis $\mathrm{C}$ virus infection in hemodialysis patients. J Clin Lab Anal 13: 122-125.

Hopf U, Berg T, Konig V, Kulher S, Heuf H, Lobeck H 1996. Treatment of chronic hepatitis $\mathrm{C}$ with interferon alpha: longterm follow-up and prognostic relevance of $\mathrm{HCV}$ genotypes. J Hepatol 24: 67-73.

Lewis-Ximenez LL, Oliveira JM, Mercadante LA, De Castro L, Santa CW, Stuver S, Yoshida CF 2001. Serological and vaccination profile of hemodialysis patients during an outbreak of hepatitis B virus infection. Nephron 87: 19-26.

Lok ASF, Gunaratnam NT 1997. Diagnosis of hepatitis C. Hepatology 26(Suppl. I): 48S-56S.
McOmish F, Yap PL, Dow B, Follett EAC, Seed C, Keller AJ, Cobain TJ, Krusius T, Kolho E, Naukkarinen R, Lin C, Lai C, Leong S, Medgyesi GA, Hejjas M, Kiyokawa H, Fukada K, Cuypers T, Saeed AA, Al-Rasheed AM, Lin M, Simmonds P 1994. Geographical distribution of hepatitis C virus genotypes in blood donors: an International Collaborative Survey. J Clin Microbil 322: 884-889.

Oliveira GC, Carmo RA, Rocha MO, Guimaraes MD, CorrêaOliveira R 1999. Hepatitis C virus genotypes in hemophiliacs in the State of Minas Gerais, Brazil. Transfusion 39: 1194-1199.

Oliveira MLA, Bastos FI, Sabino RR, Paetzold U, Schreier E, Pauli G, Yoshida CFT 1999. Distribution of HCV genotypes among different exposure categories in Brazil. Braz J Med Biol Res 32: 279-282.

Sharara AI, Hunt CM, Hamilton JD 1996. Hepatitis C. Ann Intern Med 125: 658-668.

Takada N, Takase S, Takada A, Date T 1993. Differences in the hepatitis $\mathrm{C}$ virus genotypes in different countries. $J$ Hepatol 17: 277-283.

Teles SA, Martins RM, Silva AS, Gomes DM, Cardoso DD, Vanderborght BO, Yoshida CF 1998. Hepatitis B virus infection profile in central Brazilian hemodialysis population. Rev Inst Med Trop São Paulo 40: 281-286.

Tokars JI, Miller ER, Alter MJ, Arduino MJ 1998. National surveillance of dialysis associated diseases in the United States. ASAIO J 44: 98-107.

Wreghitt TG 1999. Blood-bore virus infections in dialysis units - a review. Rev Med Virol 9: 101-109. 